\title{
Epidemiological Evidence of the Effects of Environmental Pollution on Male Reproductive Health in an Electronic Waste-Recycling Town
}

\author{
Han Dü ${ }^{1 \#}$, Mengxi Yu", Jun Sun ${ }^{1}$, Gaihuan Song ${ }^{3}$, Yan Li ${ }^{1 *}$ \\ 'Department of Anatomy, Histology and Embryology, Medical School of Ningbo University, \\ Ningbo 315211, Zhejiang, China \\ ${ }^{2}$ Department of Diagnostic Imaging Center, Affiliated Jilin Hospital of Jilin University, Jilin 132000, China \\ ${ }^{3}$ Department of Obstetrics and Gynecology, Affiliated Hospital of Medical School of Ningbo University, \\ Ningbo, Zhejiang 315000, China
}

Received: 9 March 2015

Accepted: 18 March 2016

\begin{abstract}
In recent years have seen increasing evidence linking occupational and environmental exposure to toxic pollutants with human male reproductive disorders. The aim of this study was to collect epidemiological information on male reproductive health to explore the effects of electronic waste (e-waste) environmental pollution on male genital health in Wenling, one of the world's biggest e-waste recycling centers. We collected clinic information from 2001 to 2012 in Wenling covering male reproductive diseases, including prostatitis, epididymitis, orchitis, urinary tract infections, cystospermitis, impotence, condyloma accuminatum, syphilis, gonorrhea, varicocele, genital herpes, prostatic carcinoma, etc. The morbidity of male reproductive diseases in Wenling was higher than in the control area - especially those diseases that could be influenced by environmental factors. Male reproductive health may be threatened by e-waste pollution in Wenling, and this could influence local population diathesis.
\end{abstract}

Keywords: environmental pollution, e-waste, male reproduction, morbidity

\section{Introduction}

Reports of declining sperm quantity and quality over the past 50 years have alerted scientists and clinicians to the possibility that exposure to chemicals in the environment might damage male reproductive health. Environmental or occupational exposure can lead to abnormal reproductive

\footnotetext{
\# These authors contributed equally to this manuscript.

*e-mail: liyan@nbu.edu.cn
}

outcomes by altering the integrity of genetic material at a chromosomal or DNA level in male sperm cells [1]. Male reproductive disorders have become an important public health issue, as they may cause miscarriages and abnormal outcomes in the offspring.

Wenling, a town in the southern province of Zhejiang, China, has a near 20-year history of electronic e-waste recycling, which is often performed by family-run workshops using uncontrolled methods that damage the environment and threaten health [2-4]. Several studies have reported residents that live in e-waste recycling areas to have high levels of toxic heavy metals [5-9] and the highest 
documented levels of atmospheric polychlorodibenzo$p$-dioxins (PCDDs), polychlorodibenzofurans (PCDFs) and polybrominated diphenyl ether (PBDE) in the world $[10,11]$. Therefore, we have assumed that male reproductive health might be influenced by local e-waste environmental pollution.

To explore the effects of e-waste environmental pollution on male reproductive health, our aim was to collect epidemiological information on male reproductive diseases in Wenling. We retrospectively reviewed clinic case information from 2001 to 2012 in Wenling and a control hospital. We hope this will become a reference for further research on environmental reproductive toxicity.

\section{Materials and Methods}

\section{Study Populations}

Wenling is situated in southeastern Taizhou $\left(28^{\circ} 01^{\prime}\right.$ $29^{\circ} 20^{\prime} \mathrm{N}, 120^{\circ} 11^{\prime}-121^{\circ} 56^{\prime} \mathrm{E}$ ) in eastern Zhejiang Province in southeastern China (Fig. 1). The region has a coastline of $745 \mathrm{~km}$, accounting for $28 \%$ of the province. Wenling has approximately 30 villages heavily involved in a 20 -year history of recycling e-waste. This e-waste is disassembled and shattered into powder to select the usable materials, and discarded e-waste powder is stacked around some villages. There are two hospitals in Wenling: Wenling 1 and Wenling 2, both of which have the same size and profile. There is a special reproductive department in Wenling 1 but not in Wenling 2, so most reproductive patients go to Wenling 1. From 2001-12, Wenling had 3,195 male patients with reproductive diseases.

Control clinic case information come from Wenzhou regional hospital. Wenzhou $\left(27^{\circ} 03^{\prime}-28^{\circ} 36^{\prime} \mathrm{N}, 119^{\circ} 37^{\prime}-\right.$ $\left.121^{\circ} 18^{\prime} \mathrm{E}\right)$ is also situated in eastern Zhejiang Province. It is also near the sea, approximately $100 \mathrm{~km}$ from Wenling, and is not involved in e-waste recycling. The population, traffic density, cultural background, lifestyle, and socioeconomic status of the two cities are similar. Wenzhou regional hospital, which is of the same grade and scale as Wenling hospital, saw 1,307 cases of male

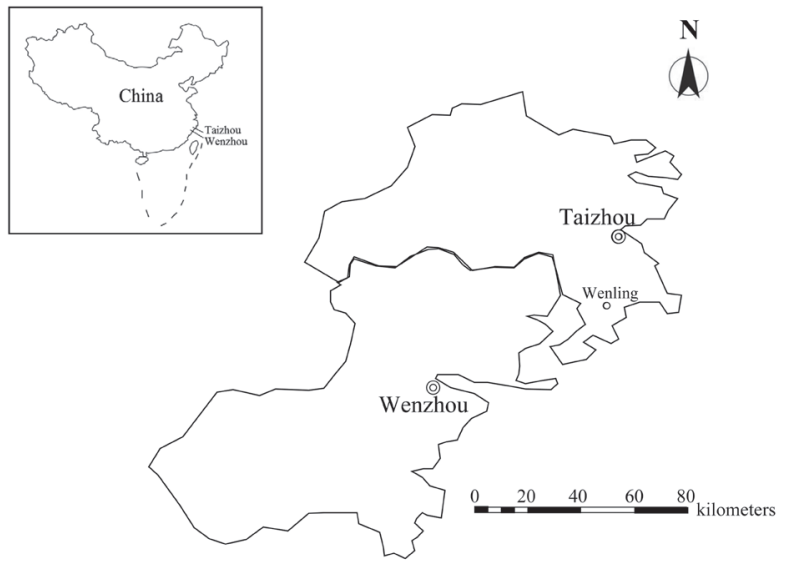

Fig. 1. The map of Wenling and Wenzhou. reproductive disease in 2001-12.

\section{Questionnaire}

The self-reporting questionnaire was designed by our department. The first item on the questionnaire included the subject's current age, name, and nationality. The second part concerned the urogenital system, including penile anatomy (microphallus, phimosis, redundant prepuce, or any scar of

Table 1. Morbidity of various kinds of male genital diseases in Wenling and control.

\begin{tabular}{|c|c|c|c|}
\hline Group & $\begin{array}{c}\text { Wenling } \\
1\end{array}$ & $\begin{array}{c}\text { Wenling } \\
2\end{array}$ & Control \\
\hline Prostatitis & 71 & 87 & 24 \\
\hline Carcinoma of prostate & 267 & 102 & - \\
\hline Urethritis & 646 & 72 & 862 \\
\hline Carcinoma of testis & 6 & 1 & 6 \\
\hline Epididymitis & 303 & 93 & - \\
\hline Prepuce balanitis & 11 & - & - \\
\hline Orchitis & 62 & 4 & - \\
\hline Impotence & - & - & 9 \\
\hline Condyloma acuminatum & 51 & 13 & 9 \\
\hline Seminal vesiculitis & 16 & 8 & 3 \\
\hline Redundant prepuce & 96 & 198 & 43 \\
\hline Syphili & 34 & 11 & 3 \\
\hline Gonorrhea & - & - & 2 \\
\hline Varicocele & - & 87 & 326 \\
\hline Genital herpes & - & - & 2 \\
\hline $\begin{array}{l}\text { Unknown origin male } \\
\text { infertility }\end{array}$ & - & 6 & - \\
\hline Scrotal mass & 15 & - & - \\
\hline Oscheocele & 3 & - & - \\
\hline Abscess of scrotum & 3 & - & - \\
\hline Boil of scrotum & 2 & - & - \\
\hline Hydrocele cyst & 4 & - & - \\
\hline Hydrocele & 683 & - & - \\
\hline Funicular hydrocele & 122 & - & - \\
\hline Spermatocele & 9 & - & - \\
\hline $\begin{array}{l}\text { Epididymal sperm } \\
\text { granuloma }\end{array}$ & 6 & - & - \\
\hline Testicular tumor & 5 & - & - \\
\hline Deferentitis & 2 & - & - \\
\hline Plastic induration & 2 & - & - \\
\hline Acquired penile deformity & 3 & - & - \\
\hline Total & 2523 & 672 & 1307 \\
\hline
\end{tabular}


an external injury), testicular anatomy (tiny testis, absent testis, Klinefelter syndrome, soft testis, cryptorchidism), epididymal function (epididymitis, tubercle, tenderness), and deferent duct function (thickening, tubercle, tenuity, absence). The third concerned male reproductive diseases, including prostatitis, epididymitis, preputial balanitis, orchitis, urinary tract infections, impotence, condyloma acuminatum, seminal vesiculitis, redundant prepuce, syphilis, gonorrhea, varicocele, genital herpes, urethritis, abnormal sexual function, prostatic carcinoma, carcinoma of the testis, etc. We did not gather data of a fourth item because this was a retrospective survey.

\section{Statistical Analysis}

Data were analyzed using SPSS (Statistic Package for Social Science, version 14.0, SPSS Institute, Inc., Cary, NC, USA). Differences in the morbidity of male genital diseases between exposed and unexposed subjects were tested using chi-square tests. For all analyses, the term statistically significant is used to denote a two-sided p-value less than $5 \%$.

\section{Results}

\section{Morbidity of Various Kinds of Male Reproductive Diseases in Wenling and the Control Hospital}

The morbidity of male reproductive diseases is listed in Table 1 . The overall morbidity of male reproductive diseases reported in Wenling was higher than in the control hospital. The morbidity of prostatitis, carcinoma of prostate, carcinoma of testis, epididymitis, condyloma acuminatum, seminal vesiculitis, redundant prepuce, syphilis, and orchitis in Wenling were all higher than in the control hospital. In contrast, the morbidity of urethritis and varicocele were higher in the control hospital than in Wenling. The following diseases don't have integrity data: prepuce balanitis (11), unknown origin male infertility (6), scrotal mass (15), oscheocele (3), abscess of scrotum (3), boil of scrotum (2), hydrocele cyst (4), hydrocele (683), funicular hydrocele (122), spermatocele (9), epididymal sperm granuloma (6), testicular tumor (5), deferentitis (2), plastic induration (2), and acquired penile deformity (3) only have Wenling1 hospital data, and impotence (9), gonorrhea (2), and genital herpes (2) only have data of control hospital.

\section{Discussion}

The morbidity rates of male reproductive diseases in Wenling were higher than in the control hospital especially for those diseases that can be influenced by environmental factors. But the morbidity of urethritis and varicocele were higher in the control hospital than in Wenling, and some diseases don't have integrity data.

Heavy metal and persistent organic pollutants (POP) pollution have been monitored in the Wenling environment [3-5]. Lead pollution might affect sperm chromatin by altering the availability of zinc to spermatozoa [12]. It was also reported that even low levels of cadmium accumulation in semen might contribute to male infertility by reducing sperm quality [13]. Chromium and copper are essential for good health but might be harmful above certain levels. These metals act as cofactors for a variety of important enzymes, but have been associated with reduced semen quality in rodents and humans [14]. Therefore, spermatogenesis and the semen quality of adult men living in Wenling might be affected by e-waste environmental pollution, leading to the higher local incidence of male reproductive disorders in this area. In the result, the morbidity of urethritis and varicocele were higher in the control hospital than in Wenling. These two kinds of diseases have little relationship with environmental pollution, and the result should be no significant difference in Wenling and control area. We think that the reasons are the size of the hospital, the sections of classification, and the way we got the data. There are some incomplete data, but we will collect further information on this part.

In conclusion, the morbidity rates of male reproductive diseases in Wenling were higher than in the control hospital, especially for those diseases that can be influenced by environmental factors. Male reproductive health could be threatened by e-waste environmental pollution in Wenling, and that could influence local population diathesis. Further studies on the detection and control of reproductive hazards at work should be of high priority.

\section{Acknowledgements}

This work was supported by the Natural Science Foundation of Ningbo (2015A610233), the science and technology "Fumin and Huimin" Project of Ningbo (2015C50018), and was sponsored by the K.C. Wong Magna Fund in Ningbo University.

\section{References}

1. WYROBEK A.J. Methods and concepts in detecting abnormal reproductive outcomes of paternal origin. Reprod Toxicol. 7 (1), 3, 1993.

2. BEN Y.J., LI X.H., YANG Y.L., LI L., DI J.P., WANG W.Y., ZHOU R.F., XIAO K., ZHENG M.Y., TIAN Y., XU X.B. Dechlorane Plus and its dechlorinated analogs from an e-waste recycling center in maternal serum and breast milk of women in Wenling, China. Environmental Pollution. 173, 176, 2013.

3. TANG X., SHEN C., SHI D., CHEEMA S.A., KHAN M.I., ZHANG C., CHEN Y. Heavy metal and persistent organic compound contamination in soil from Wenling: An emerging e-waste recycling city in Taizhou area, China. Journal of Hazardous Materials. 173 (1-3), 653, 2010.

4. JIN J., JIANG C., THUY T.D., LI L. Public preferences for cultivated land protection in Wenling City, China: A choice experiment study. Land Use Policy. 30 (1), 337, 2013. 
5. YANG Y., LU X.S., LI D.L., YUY.J. Effects of Environmental Lead Pollution on Blood Lead and Sex Hormone Levels among Occupationally Exposed Group in An E-waste Dismantling Area. Biomedical and Environmental Sciences. 26 (6), 474, 2013.

6. ZHANG W.H., WU Y.X., SIMONNOT M.O. Soil Contamination due to E-Waste Disposal and Recycling Activities: A Review with Special Focus on China. Pedosphere. 22 (4), 434, 2012.

7. WONG C.S., DUZGOREN-AYDIN N.S., AYDIN A., WONG M.H. Evidence of excessive releases of metals from primitive e-waste processing in Guiyu, China. Environ Pollut. 148 (1), 62, 2007.

8. WONG M.H., WU S.C., DENG W.J., YU X.Z., LUO Q., LEUNG A.O., WANG C.S., LUKSEMBURG W.J., WONG A.S. Export of toxic chemicals - a review of the case of uncontrolled electronic-waste recycling. Environ Pollut. 149 (2), 131, 2007.

9. LEUNG A.O., DUZGOREN-AYDIN N.S., ChEUNG K.C., WONG M.H. Heavy metals concentrations of surface dust from e-waste recycling and its human health implications in southeast China. Environ Sci Technol. 42 (7), 2674, 2008.

10. LI H., YU L., FU J., PENG P. Severe PCDD/F and PBDD/F pollution in air around an electronic waste dismantling area in China. Environ Sci Technol. 41 (16), 5641, 2007.

11. BI X., THOMAS G.O., JONES K.C., QU W., SHENG G., MARTIN F.L., FU L. Exposure of electronics dismantling workers to polybrominated diphenyl ethers, polychlorinated biphenyls, and organochlorine pesticides in South China. Environ Sci Technol. 41 (16), 5647, 2007.

12. HERNANDEZ-OCHOA I., GARCIA-VARGAS G., LOPEZ-CARRILLO L., RUBIO-ANDRADE M., MORANMARTINEZ J., CEBRIAN M.E., QUINTANILLA-VEGA B. Low lead environmental exposure alters semen quality and sperm chromatin condensation in northern Mexico. Reprod Toxicol. 20 (2), 221, 2005.

13. WU H.M., LIN-TAN D.T., WANG M.L., HUANG H.Y., WANG H.S., SONG Y.K., LIN J.L. Cadmium level in seminal plasma may affect the pregnancy rate for patients undergoing infertility evaluation and treatment. Reprod Toxicol. 25 (4), 481, 2008.

14. MEEKER J.D., ROSSANO M.G., PROTAS B., DIAMOND M.P., PUCHECK E., DALY D., PANETH N., WIRTH J.J. Cadmium, lead, and other metals in relation to semen quality: human evidence for molybdenum as a male reproductive toxicant. Environ Health Perspect. 116 (11), 1473, 2008. 